\title{
PREDICTION OF MICROFIBRIL ANGLE FOR Eucalyptus microcorys WOOD BY FIBER LENGTH AND BASIC DENSITY
}

\author{
Luiz Eduardo de Lima Melo ${ }^{1, \AA}$, Selma Lopes Goulart', Bárbara Maria Ribeiro Guimarães ${ }^{3}$, \\ Rosalvo Maciel Guimarães Neto ${ }^{4}$, Caroline Junqueira Sartori ${ }^{5}$, José Tarcísio Lima ${ }^{3}$
}

\begin{abstract}
Aim of the study was to estimate the influence of the fiber length and basic density on microfibril angle of Eucalyptus microcorys wood. The study area was in an experimental planting at the Universidade Federal de Lavras, Minas Gerais State, Brazil. Three 37 year-old Eucalyptus microcorys trees were used, from whose stems six centimeter-thick discs were removed, cut at a high of three meters. The disks were sanded and planed to highlight the growth rings. Specimens were taken every $1,5 \mathrm{~cm}$ across the radius from pith to bark for determining microfibril angle, fiber length and wood basic density. The microfibril angles were determined by use of polarized light microscopy, while the fiber morphology and basic density were determined by usual methods. The averages found for microfibril angle $\left(12,6^{\circ}\right)$, fiber length $(968 \mu \mathrm{m})$ and basic density $\left(480 \mathrm{~kg} . \mathrm{m}^{-3}\right)$ are, in general, within the range of values reported for these characteristics of wood. The microfibril angle showed accentuated reduction of the average values in the pith-bark direction. The fiber length and basic density showed the opposite behavior. We observed that the density and fiber length may be used as a microfibril angle predictor, accounting for $96 \%$ and $79 \%$ of its variation, respectively.
\end{abstract}

Keywords: Eucalypt, fiber morphology, microfibril slope, specific gravity, wood variation.

\section{INTRODUCTION}

Eucalyptus microcorys is a naturally occurring species in northern New South Wales and Queensland, Australia, between latitudes $25^{\circ}$ and $32,5^{\circ} \mathrm{S}$ at altitudes ranging from sea level to 800 $\mathrm{m}$. This species is known in Australia for Tallow wood and can reach 35 to $60 \mathrm{~m}$ in height and 1,5 to $2 \mathrm{~m}$ in DBH (Boland et al. 2006). Its wood presents good characteristics not only for laminating, but also for making furniture and boxes, as well as for construction and uses such as poles and pillars, and tolerant to fire. It is one of the species that have received special attention in Australia, given their high value as wood for sawmill (Neves 2004). In addition to use in the timber industry, this species also has great medicinal potential as its essential oil is rich in 1,8-cineol (86,7\%) (Foudil-Cherif et al. 2000, Estanislau et al. 2001). In general, it has short $(1,32 \mathrm{~mm})$ and narrow $(19,8 \mathrm{~mm})$ fibers, with a mean

\footnotetext{
${ }^{1}$ Universidade do Estado do Pará. Campus VIII, Departamento de Tecnologia e Recursos Naturais, Laboratório de Ciência e Tecnologia da Madeira, Marabá, Pará, Brazil

${ }^{2}$ Universidade Federal Rural da Amazônia. Campus Paraupebas, Paraupebas, Pará, Brazil

${ }^{3}$ Universidade Federal de Lavras, Departamento de Ciências Florestais, Lavras, Minas Gerais, Brazil

${ }^{4}$ Universidade Federal do Piauí, Bom Jesus, Piauí, Brazil

${ }^{5}$ Instituto Federal de Minas Gerais - Campus São João Evangelista, São João Evangelista, Minas Gerais, Brazil

•Corresponding author: luizeduardo.limamelo@gmail.com

Received: 17.06.2017 Accepted: 11.04.2018
} 
wall thickness of 5,8 $\mathrm{m}$ and a lumen of 8,1 $\mathrm{m}$ (Tomazello-Filho 1985).

In Brazil, E. microcorys is not planted commercially, but there are some provenance tests installed to evaluate its adaptation and wood quality. One of these tests was installed on the farm of the Federal University of Lavras in 1975. According to Pires (2010), this test was established with seedlings produced from Australian seeds, that is, it is a totally wild genetic material with no degree of improvement, thus being material of great importance for conservation, able to serve as a genetic bank.

With wood from the same trees used in this work, Martins et al. (2013) evaluated E. microcorys for use as flooring. They verified that the wood presented a basic density of $795 \mathrm{~kg} \cdot \mathrm{m}^{-3}$, tangential shrinkage $9,8 \%$ and radial shrinkage of $6,5 \%$. The mechanical behavior of the wood was assessed through tests of rolling roll application, static and dynamic friction, indentation caused by loads applied in small areas, falling steel sphere impact and abrasion resistance. With these tests simulating conditions of use as flooring, the authors verified that there is technical feasibility for the use of E. microcorys wood under severe conditions. Also for the same trees, Goulart et al. (2015) found that the wood dynamic modulus of elasticity, evaluated by transverse vibration tests, was $20 \mathrm{MPa}$, similar to woods of E. saligna, $E$. pilularis and E. urophylla.

Despite its importance, the durability of E. microcorys wood has not yet been tested for Brazilian environmental conditions. However, Grace et al. (1996) report that this wood, tested for Hawaiian conditions, was very resistant to a termite feeding test.

In view of the importance of wood quality for its rational and sustainable use, in recent years, together with the rapid increase in the activity of forest genetic improvement, numerous studies have been carried out on the intra- and inter-specific variability of anatomical and physical characteristics of various timber species, and how they relate to the quality of timber. Most of these studies are based mainly on the variations of density, microfibril angle and fiber length, in order to better understand the relation of these properties to the production of wood or other products (Palermo et al. 2015).

According to Wimmer et al. (2002), the microfibril angle is one of the most important aspects of the cell wall. The angle formed by the microfibrils with the fiber axis is related to the length and individual strength of the fiber. The orientation of the microfibrils in the S2 layer confers high tensile strength to the plant fiber. Lower angle values correlate to high tensile strengths (Navi et al. 1995). Thus, from the knowledge of these characteristics a better use of the wood in its applications is possible.

Cellulosic microfibrils are the fundamental units of the cell wall of plant anatomical elements. The wood fiber cell wall is composed of the primary and secondary walls (S1, S2, S3). The S2 layer is thicker $(1-10 \mu \mathrm{m})$ and represents $75-85 \%$ of the total thickness of the cell wall. The orientation of the microfibrils in this layer forms an angle with the axis of the fibers of between $5^{\circ}$ and $30^{\circ}$, the layer being most influential in the physical and mechanical properties of wood (Donaldson 2008). The longitudinal modulus of elasticity $\left(\mathrm{MOE}_{\mathrm{I}}\right.$ ), for example, is dependent on the MFA of layer S2 (Cave 1968). The S1 layer is thinner $(0,1$ to $0,35 \mu \mathrm{m})$ representing between 5 and $10 \%$ of the total thickness of the cell wall, with microfibrils with angles of $60^{\circ}$ to $80^{\circ}$. The $\mathrm{S} 3$ layer has between 0,5 and $1 \mu \mathrm{m}$ of thickness, forming angles between $60^{\circ}$ and $90^{\circ}$ relative to the cell axis (Plomion et al. 2001, Mellerowiicz et al. 2001). Although less thick, the layers S1 and S3 play a crucial role in reinforcing the cell against deformation by water stress forces, lateral hardness and wood resistance to crushing (Booker 1993).

The thickness, length and width of the fibers associated to the inclination of the microfibrils in relation to its axis are important for defining wood physical and mechanical properties such as dimensional stability, stiffness and mechanical strength (Barnett and Bonha 2004, Chauhan et al. 2006).

Lima et al. (2004) found MFA between $7,1^{\circ}$ and $11,1^{\circ}$ in wood of young Eucalyptus clones. Ramos et al. (2011) and Lima et al. (2014) found that for Eucalyptus grandis MFA generally decreases with increasing cambial age. Ramos et al. (2011) found MFA decreasing from $30,24^{\circ}$ to $23,79^{\circ}$ in the pith to bark direction in trees 23 years of age and Lima et al. (2014) found a range of $29,3^{\circ}$ to $18,9^{\circ}$ in the same direction for 25 year-old trees.

The MFA maintains variable ratio to the density and may have some correlation between successive rings, but does not show the same behavior amongst trees of the same species (Evans et al. 2000). Donaldson (2008) reports that as the MFA ranges between early and late wood and therefore its amount 
in the wood influences the density, the relationship between the MFA and density may be spurious.

Evans et al. (2000) observed that there was some correlation between the density and MFA in Eucalyptus nitens wood. Although it is significant only for correlations between different radial points within the tree in a small number of consecutive growth rings, this relationship between the MFA and density is not consistent among trees. Hein et al. (2011) concluded that there was no significant correlation between MFA and wood density in E. urophylla at age 14. The study of the interactions between the different properties of wood has become increasingly important for the production of quality raw material, thus, knowledge of which traits and properties are most influential for survival at different life stages, and under different stress regimes, will help managers choose the species and cultivars that are best suited for different sites and management goals for forested, agricultural and wild lands of the future (Lachenbruch and McCulloh 2014).

The studies relating MFA to other properties of hardwood, as is the case of Eucalyptus microcorys, are scarce, which requires further investigation. We investigated the pith-bark variation of fiber length and wood density, which are relatively simple properties to be determined. Thus, the main objective consisted of estimating the microfibril angle of Eucalyptus microcorys wood through the fiber length and basic density.

\section{MATERIALS AND METHODS}

\section{Materials}

For the present study we used wood of three 37 year-old Eucalyptus microcorys F. Muell trees with an average dbh of 33,3 cm, coming from an existing experimental planting in Lavras, Minas Gerais State, Brazil, located at an average altitude of $914 \mathrm{~m}$ ( $21^{\circ} 14$ ' $30^{\prime}$ ' $\mathrm{S} 45^{\circ} 00^{\prime} \mathrm{W} 10$ ') $)$. The trees were planted in spacing of 3,0 x 2,0 m and selected among the dominant and co-dominant, without tortuosity and bifurcation. When cut, they had a mean dbh of $50,9 \mathrm{~cm}$ and a total height of $35 \mathrm{~m}$. Sampling was done on a $300 \mathrm{~cm} \mathrm{log}$, cut between 300 and $600 \mathrm{~cm}$ in height of the trunk since the basal log had been used for other studies.

\section{Methods}

A $6 \mathrm{~cm}$ thick disk was cut at a stem height of three meters. Specimens of $1,5 \mathrm{~cm}$ from pith to bark were removed from the sample, in order to determine wood density, fiber length and microfibril angle (MFA).

The basic density was determined according to NBR 11941 (ABNT, 2003). To individualize the fibers the maceration method by Franklin (1945) was used, modified by Kraus and Arduim (1997); $1 \%$ aqueous safranin dye was used to stain these cells, in order to measure the fiber lengths for each maceration. For the MFA measurement, initially, the $1 \mathrm{~cm}^{3}$ wood samples were saturated in water and sectioned in tangential histological sections of $7 \mu \mathrm{m}$ using a sliding microtome. This thin section followed the recommendation by Leney (1981), which emphasizes the need for fibers cut in half, lengthwise (half-fiber). For the MFA measurement, temporary slides were prepared in solution of distilled water and 1\% glycerine. MFA was determined in 30 fibers from each sample using the polarized light microscopy proposed technique by Preston (1974), and adopted by Lima et al. (2004), by a microscope equipped a with turntable and a goniometer graduated from $0^{\circ}$ to $360^{\circ}$.

Histological sections were placed in glass flasks with a solution of glacial acetic acid and hydrogen peroxide at a 1:1 ratio (Franklin 1945 modified by Berlyn and Miksche 1976). The flasks were capped and put in an oven at $60^{\circ} \mathrm{C}$ for 24 hours for disaggregation of anatomical elements, resulting in a macerated material which was then washed and stored in distilled water.

For the evaluation of wood characteristics, analysis of variance (ANOVA) was carried out with values of all raw data obtained, meaning three trees, eleven radial points on each tree, in the case of fiber length and MFA 30 measurements and for the basic density about two specimens. To evaluate 
how wood density, fiber length and microfibril angle varied with a distance from the pith to the next to the cambium of trees, we first used a piecewise regression to determine if a breakpoint (an abrupt change in a relationship) in our data was present. As all of our data presented normal distribution, we applied only a linear model (LM). Using this model we performed a piecewise regression (using the segmented package in software R). To identify the most plausible models, we performed a model selection procedure based on Akaike information criterion (AICc) in which we compared AICc model weights across models with all possible variable combinations, we always select the model with the lowest AICc (following Ochoa-Quintero et al. 2015, Magnago et al. 2015). The piecewise regression allowed us to determine whether there was a significant influence of distance and to identify any discrete breakpoint in some of the evaluated wood properties $(\mathrm{P}<0,05)$. From the average values in the eleven radial positions sampled on the three tree discs, Pearson correlation analysis and linear regression were conducted to verify the dependence relationships of the MFA on the fiber lengths and wood density.

\section{RESULTS AND DISCUSSION}

\section{Wood characteristics of Eucalyptus microcorys}

The Eucalyptus microcorys wood showed an average microfibril angle (MFA) of 12,6 $6^{\circ}$; average fiber length (FL) of $968 \mu \mathrm{m}$, classified as medium-length fibers $(900-1600 \mu \mathrm{m})$ and a mean density of $480 \mathrm{~kg} . \mathrm{m}^{-3}$, classified as medium density wood (400 to $\left.750 \mathrm{~kg} \cdot \mathrm{m}^{-3}\right)$ (Table 1$)$. The classifications of the FL and density are according to the IAWA Committee (1989).

Table 1. Descriptive statistics of microfibril angle (MFA), fiber length (FL) and basic density (BD).

\begin{tabular}{|l|c|c|c|}
\hline & MFA $($ degree $)$ & FL $(\mu \mathrm{m})$ & BD $\left(\mathrm{kg} . \mathrm{m}^{-3}\right)$ \\
\hline Minimum & 7,5 & 535 & 350 \\
\hline Average & 12,6 & 968 & 480 \\
\hline Maximum. & 17,5 & 1330 & 570 \\
\hline Coefficient of variation (\%) & 24,27 & 22,83 & 13,68 \\
\hline
\end{tabular}

According to Wilkes and Abbott (1983), Bamber (1985) and Wilkes (1988) the FL, in the majority of Eucalyptus species, varies between 800 and 1300 micrometers. The value obtained in E. microcorys wood studied by Tomazello-Filho (1985) is about 1000 micrometers. For BD, Tomazello-Filho (1985) found $560 \mathrm{~kg} \cdot \mathrm{m}^{-3}$, higher than $480 \mathrm{~kg} \cdot \mathrm{m}^{-3}$ presented in Table 1 . However, this value lies within the category of medium-density wood, according to the classification of the IAWA Committee (1989). The average MFA found for E. microcorys wood is close to averages observed for angiosperms, ranging from $5^{\circ}$ to $20^{\circ}$, as reported by Boyd (1985). In general, there are few studies on MFA with genetic materials of Eucalyptus at more advanced ages, since most studies are conducted with young trees, which form only juvenile wood. Hirohashi et al. (2012) determined the MFA in several species of Eucalyptus spp, and found MFA of $12,6^{\circ}$ for E. elata, formerly known as E. andreana, at around 25 years of age, close to the angle found for species in this present study. 


\section{Variation of the wood properties in the pith-bark direction}

Analysis of variance demonstrated that the effect of the radial position was significant at the $5 \%$ level of significance by $\mathrm{F}$ test for the wood properties (Table 2).

Table 2. Summary of the analysis of variance for the microfibril angle (MFA), the fiber length (FL), basic density (BD).

\begin{tabular}{|c|c|c|c|c|}
\hline \multicolumn{5}{|c|}{ MFA (degree) } \\
\hline Source of variation & Df & Mean square & $\mathrm{F}$ & $\mathrm{p}$-value \\
\hline RP & 10 & $20,8^{*}$ & 22,7 & $<0,05$ \\
\hline Error & 11 & 0,9 & - & - \\
\hline \multicolumn{5}{|l|}{$\mathrm{CV}_{\exp }(\%)=7,9$} \\
\hline \multicolumn{5}{|c|}{$\mathrm{FL}(\mu \mathrm{m})$} \\
\hline Source of variation & Df & Mean square & $\mathrm{F}$ & $\mathrm{p}$-value \\
\hline $\mathrm{RP}$ & 10 & $108070,9^{*}$ & 28,2 & $<0,05$ \\
\hline Error & 11 & 3831,9 & - & - \\
\hline \multicolumn{5}{|l|}{$\mathrm{CV}_{\text {exp }}(\%)=6,1$} \\
\hline \multicolumn{5}{|c|}{$\mathrm{BD}\left(\mathrm{kg} \cdot \mathrm{m}^{-3}\right)$} \\
\hline Source of variation & Df & Mean square & $\mathrm{F}$ & $\mathrm{p}$-value \\
\hline RP & 10 & $0,000081 *$ & 10,6 & $<0,05$ \\
\hline Error & 11 & 0,000008 & - & - \\
\hline $\mathrm{CV}_{\exp }(\%)=5,6$ & & & & \\
\hline
\end{tabular}

df: degrees of freedom; RP: radial position; $\mathrm{CV}_{\text {exp }}(\%)$ : experimental coefficient of variation; ${ }^{\text {ns: }}$ non significant by $\mathrm{F}$ test at $5 \%$ of significance; *: significant at 5\% of significance by F test. Number of observations: 33.

Figure 1 shows that the FL increase from pith to bark, while the MFA is reduced by $56 \%$ in the pithbark direction.
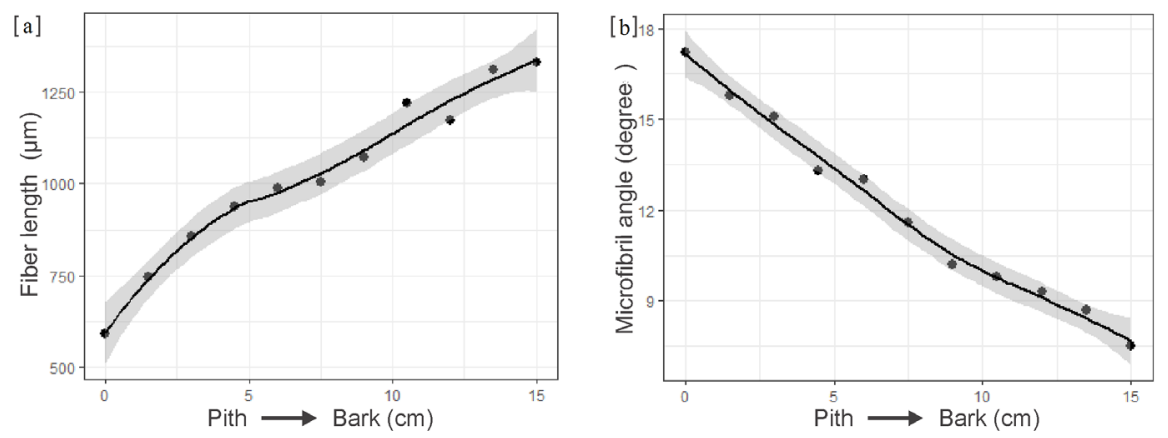

Figure 1. Variation of the fiber length (a) and microfibril angle (b) of E. microcorys wood from pith to bark. Grey shaded areas represent standard error (SE) around the mean values.

For the relationship between radial position and FL $(127,2>124,2$ AIC) and with the MFA $(22,5$ $>21,4$ AIC) higher AIC values were observed for the segmented model compared to the linear model, indicating that there is no significant threshold in the relationship of these properties to the radial distance from the pith (Figure 1). We found a threshold only in the relationship between BD and the radial distance from the pith toward the bark, this property produced lower AIC values than the results 
obtained from linear models with the same set of variables $(-36,7<-36,0$ AIC) breakpoint $=13,13$ and standard error $(\mathrm{SE})=0,52$ (Figure 2). Figure 2 shows that the BD, in general, increases from pith to bark, but we observe that the density values became stable from $13 \mathrm{~cm}$ from the pith.

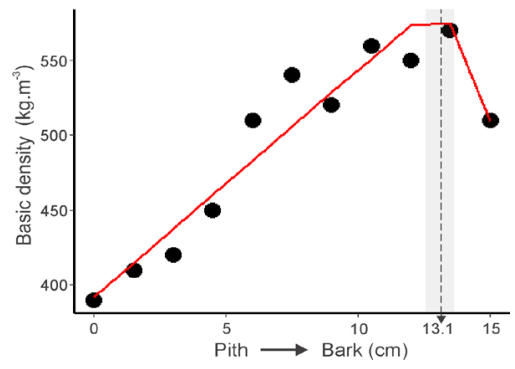

Figure 2. The effect of radial distance from the pith to the next to the bark $(\mathrm{cm})$ on the basic density $\left(\mathrm{kg} . \mathrm{m}^{-3}\right)$ of E. microcorys wood. Solid red line is based on piecewise regression, dashed vertical line represent significant breakpoint $(\mathrm{p}<0,05)$, and grey shaded areas represent SE around breakpoint distance.

The increase in FL and $\mathrm{BD}$, followed by subsequent stabilization of values close to the bark, for both or just one of the properties, is a pattern commonly described for woody species, and results mainly from the juvenile wood formation in the early years of plant growth, which over time tends toward stabilization as the wood reaches maturity (Tomazello-Filho 1987, Bhat et al. 1990). A similar variation pattern for FL was also recently described by Palermo et al. (2015) to determine the limits between adult and juvenile wood of Eucalyptus grandis wood, and for increasing behavior of BD by Hein et al. (2015) who studied the effect of terrain slope and wind velocity on the BD and other Eucalyptus grandis hybrids $\times$ E.urophylla wood properties. Melo et al. (2016) also observed a significant radial increase in fiber length and basic density in Eucalyptus spp. and Corymbia citriodora woods.

The decreasing trend in the MFA in the pith-bark direction conforms to the pattern already reported, according to which, larger angles are found in juvenile wood and smaller near the bark, showing a decrease in the pith-cambium direction for both, conifers (Donaldson 1996) and hardwoods, mainly for Eucalyptus genus (Boyd 1980, Stuart and Evans 1995). Donaldson (2008) reiterates, however, that unlike conifers, in Eucalyptus wood, the MFA is smaller near the pith, with a typical range from $15^{\circ}$ to $20^{\circ}$. The high coefficient of variation observed for MFA shows that the variation pattern found corroborates patterns in previous research, such as those described for Eucalyptus grandis (Ramos et al. 2011, Lima et al. 2014), E. nitens (Medhurst 2012) and hybrids of E. grandis $\times$ E. urophylla (Hein et al. 2015).

\section{Estimation of microfibril angle by fiber length and basic density}

The MFA showed a strong negative correlation with both FL $(r=-0,98)$ and BD $(r=-0,89)$. There was also good fit for the linear equation for the FL (Figure 3B), that was able to explain $96 \%$ of the MFA radial variation. Regarding the basic density, $79 \%$ of the MFA variation can be explained by BD (Figure 3A).
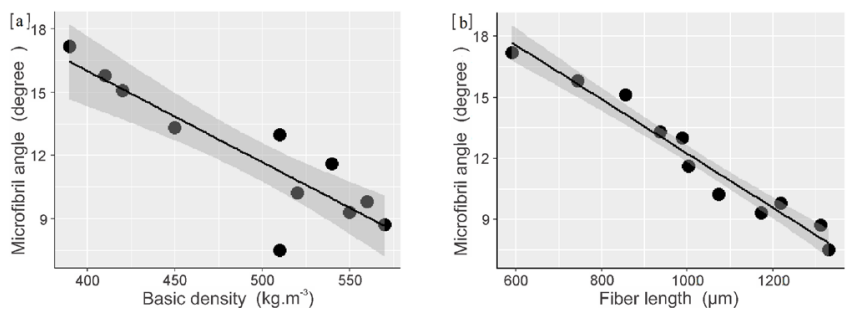

Figure 3. Estimation of microfibril angle by basic density where: $M F A=-43,52 \times B D+0,709 ; R^{2}$ $=0,79 ; \mathrm{Fc}=33,1\left(\mathrm{p}\right.$-value $\left.2,7 \times 10^{-4}\right)(\mathbf{a})$ and by fiber length where: $\mathrm{MFA}=-0,013 \mathrm{FL}+25,60 ; \mathrm{R}^{2}=$ 0,$96 ; \mathrm{Fc}=141,2\left(\mathrm{p}\right.$-value $\left.2,3 \times 10^{-6}\right)(\mathbf{b})$ of E. microcorys wood. 
Analyzing the angular coefficients of the regression obtained (Figure 3a), the relationship between MFA and FL for each $1 \mu \mathrm{m}$ increase in the FL is reduced by approximately 0,013 degrees in MFA. For the relation with the BD (Figure $3 \mathrm{~b}$ ) an increase of $100 \mathrm{~kg} \cdot \mathrm{m}^{-3}$ in the basic density is associated to a reduction of 4,35 degrees in the MFA. Thus, for this study, the increase observed in Figure 1a and Figure $1 \mathrm{~b}$, from pith to bark of $125 \%$ in FL $(738 \mu \mathrm{m})$ and of $46 \%$ in BD $\left(180 \mathrm{~kg} \cdot \mathrm{m}^{-3}\right)$ is associated with reduction of 9,5 and 7,8 degrees in the MFA, respectively.

The MFA is an important ultramicroscopic characteristic for determining the quality of wood products, and when investigated along with other properties, it becomes an important tool for technological characterization of the raw material (Meylan and Probine 1969). This research demonstrated that from the length of the E. microcorys wood fibers we can get a good estimate of the MFA for the species and their behavior from pith to bark. As presented in this present work, Bonham and Barnett (2001) for Betula pendula showed that when there was an increase in the FL in the pith to bark direction, there was an MFA reduction. These results evidence that there is a negative correlation between these properties, so the authors verified there is a strong correlation between the MFA and fiber length and between the MFA and fiber strength. On the other hand, Matsumura and Butterfield (2001) found that MFA and tracheid length were not correlated in wood of Pinus spp. For this reason, Donaldson (2008) warns of the need for more detailed assessment of this interaction, with studies comparing samples with the same cambial age among trees.

For the relationship between the MFA and density, there was good fit between the two properties. According to Donaldson (2008) it is likely that any relationship between these properties is merely coincidental, since MFA is not well related with the fiber wall thickness, however the amount of juvenile and late wood may be responsible for the existence of correlations in some cases. Evans et al. (2000) have reported, however, that the correlation between density and MFA can be stronger over a small number of consecutive growth rings, and therefore more evident in the radial direction, as was shown in the present work for E. microcorys. However, these authors confirm, curiously, that the relationship between the density and MFA was not observed among different trees. Yang and Evans (2003) reported for Eucalyptus globulus, E. nitens and E. regnans, that in general, the density was negatively correlated with MFA. We emphasize that one of the causes of the wood density increase in the pith-bark direction is related to the necessity of the tree to support the greater weight of the crown and the increase in its own stem diameter with increasing age. Thus, assuming that the reduction of the MFA is directly related to increased wood strength and stiffness, the interaction observed for this species is not only coherent but also shows that the density can be used as a good predictive parameter of the MFA for $E$. microcorys wood.

\section{CONCLUSIONS}

From the length of the wood fibers of E. microcorys, we can obtain a good estimate of the MFA for the species and their behavior in the pith to bark direction.

It was possible to estimate the MPA using the basic density and fiber length, thus making it practical to determine the variation of this important characteristic of the cell wall and thereby making wood more suitable for its rational and sustainable use.

Further studies should be performed using a larger database with more trees and different trunk heights.

More advanced studies that involve other wood characteristics for the prediction of MFA should be developed by expanding the information base to allow better use of the wood. 


\section{ACKNOWLEDGMENTS}

The authors are grateful to CAPES and CNPq (Process 311574 / 2013-0) for the grants and financial support provided during this work.

\section{REFERENCES}

Associação Brasileira de Normas Técnicas. ABNT. 2003. Madeira - determinação da densidade básica. NBR 11941. Rio de Janeiro, 6 p.

Bamber, R. K. 1985. The wood anatomy of eucalypts and papermaking. Appita Journal 38(3): 210-16.

Barnett, J.R.; Bonha, V.A. 2004. Cellulose microfibril angle in the cell wall of wood fibres. Biological Reviews 79(2): 461-472.

Berlyn, G. P.; Miksche, J.P. 1976. Botanical microtechnique and cytochemistry. New Phytologist 78: 245-255.

Bhat, K.M.; Dhamodaran, T. K. 1990. Wood density and fiber length of Eucalyptus grandis grown in Kerala, India. Wood and Fiber Science 22(1): 54-61.

Boland, D.J.; Brooker, M. I. H.; Chippendale, G.M.; Hall, N.; Hyland, B.P.M.; Johnston, R.D.; Kleinig, D.A.; Turner, J.D. 2006. Forest Trees of Australia. CSIRO Publishing. Melbourne.

Bonham, V. A.; Barnett, J.R. 2001. Fibre length and microfibril angle in silver birch (Betula pendula Roth). Holzforschung 55(2): 159-162.

Booker, R. E. 1993. The importance of the S3 cell wall layer in collapse prevention and wood hardness. In: Forest Products Research Conference, 1993, Clayton, Australia. Clayton, Australia: CSIRO, 1993: 1- 13.

Boyd, J. D. 1980. Relationships between fibre morphology, growth strains and physical properties of wood. Australian Forest Research 10(4): 337-360.

Boyd, J. D. 1985. Biophysical control of microfibril orientation in plant cell walls: aquatic and terrestrial plants including trees. Ed. M, Nijhoff; W, Junk, Hingham: Massachusetts, USA.

Cave, I.D. 1968. The anisotropic elasticity of the plant cell wall. Wood Science and Technology 2 (4):268-278.

Chauhan, S.; Donnelly, R.; Huang, C. L.; Nakada, R.; Yafang, Y.; Walker, J. 2006. Wood quality: multifaceted opportunities, in: Primary wood processing: principles and practice. Walker J Trees (ed) 2nd edn. Springer: Dordrecht, pp. 159-202.

Donaldson, L. A. 1996. Effect of physiological age and site on microfibril angle in Pinus radiata. IAWA Journal 17(4): 421-429.

Donaldson, L. 2008. Microfibril angle: measurement, variation and relationships - a review. IAWA Journal 29(4): 345-386.

Estanislau, A. A.; Barros, F. A. S.; Pena, A. P.; Santos, S. C.; Ferri, P. H.; Paula, J. R. 2001. Composição química e atividade antibacteriana dos óleos essenciais de cinco espécies de Eucalyptus cultivadas em Goiás. Revista Brasileira de Farmacognosia 11: 95-100.

Evans, R.; Stringer, S.; Kibblewhite, R. P. 2000. Variation of microfibril angle, density and fibre 
orientation in twenty-nine Eucalyptus nitens trees. Appita Journal 53(5): 450-457.

Foudil-Cherif, Y.; Meklati, B. Y.; Verzera, A.; Mondello, L.; Dugo, G. 2000. Chemical examination of essential oils from the leaves of nine Eucalyptus species growing in Algeria. J Essential Oil Res 12:186-191.

Franklin, G. L. 1945. Preparation of thin sections of synthetic resins and wood-resin composites, and a new macerating method for wood. Nature 155(3924): 51-51.

Goulart, S. L.; Arriel, T. G. ; Resende, S. S. S. ; Silva, J. R. M ; Lima, J. T.; Hein, P.R. G. 2015. Wood stiffness of Corymbia and Eucalyptus species. In: II Congresso Brasileiro de Ciência e Tecnologia da Madeira, 2015, Belo Horizonte. Anais do Ii Congresso Brasileiro de Ciência e Tecnologia da Madeira. Lavras: SBCTEM, v. 1. p. 1-10.

Grace, J.K.; Ewart, D.M.; Tome, C.H.M. 1996. Termite resistance of wood species grown in Hawaii. Forest Products Journal 46 (10): 57-60.

Hein, P. R. G.; Brancheriau, L. 2011. Radial variation of microfibril angle and wood density and their relationships in 14-year-old Eucalyptus urophylla S.T. Blake wood. Bioresources 6(3): 33523362.

Hein, P. R. G.; Chaix, G.; Clair, B.; Brancheriau, L.; Grill, J. 2015. Spatial variation of wood density, stiffness and microfibril angle along Eucalyptus trunks grown under contrasting growth conditions. Trees 29(1): 1-12.

Hirohashi, A., Kojima, M., Yoshida, M., Yamamoto, H., Watanabe, Y., Inoue, H., and Komoda, S. 2012. Wood Properties of 6 Fast-growing Eucalyptus Species Grown in Japan. Mokuzai Gakkaishi 58(6): 339-346.

International Association of Wood Anatomists Committee. 1989. IAWA list of microscopic features for hardwood identification. IAWA Bulletin 10(3): 219-332.

Ochoa-Quintero, J. M.; Gardner, T. A.; Rosa, I., Ferraz, S. F. B.; Sutherland, W. J. 2015. Threshold of species loss in Amazonian deforestation frontier landscapes. Conservation Biology 29(2): 440-451.

Kraus, J. E.; Arduim, M. 1997. Manual básico de métodos em morfologia vegetal, Universidade Federal Rural do Rio de Janeiro, Seropédica, Rio de Janeiro.

Lachenbruch, B.; McCulloh, K. A. 2014. Traits, properties, and performance: how woody plants combine hydraulic and mechanical functions in a cell, tissue, or whole plant. New Phytologist Tansley Review 204: 747-764.

Lima, J. T.; Breese, M. C.; Cahalan, C. M. 2004. Variation in microfibril angle in Eucalyptus clones. Holzforshung 58(2): 160-166.

Lima, J. T.; Ribeiro, A. O.; Narciso, C. R. P. 2014. Microfibril angle of Eucalyptus grandis wood in relation to the cambial age. Maderas-Cienc Tecnol 16(4): 487-494.

Leney, L. 1981. A technique for measuring fibril angle using polarized light. Wood and Fiber Science 13(1): 13-16.

Magnago, L. F.; Magrach, A.; Laurance, S. V. M.; Meira-Neto, J. A. A.; Simonelli, M.; Edwards, D. P. 2015. Would pretecting tropical Forest fragments tropical fragments provide carbon and biodiversity cobenefits under REDD+?. Global Change Biology 21: 3455-3468.

Martins, M.; Silva, J.R.M, Lima, J.T., Gonçalves, M.T.T.; Filipe, A.P. 2013. Simulação em uso dos pisos de madeira de Eucalyptus sp e Corymbia maculata. Cerne 19(1): 151-156. 
Matsumura, J.; Butterfield, B. G. 2001. Microfibril angles in the root wood of Pinus radiata and Pinus nigra. IAWA Journal 22(1): 57-62.

Medhurst, J.; Downes, G.; Ottenschlaeger, M.; Harwood, C.; Evans, R.; Beadle, C. 2012. Intra-specific competition and the radial development of Wood density, microfibril angle and modulus of elasticity. Trees 26(6): 1771-1780.

Mellerowiicz, E.; Baucher, M.; Sundberg, B.; Boerjan, W. 2001. Unravelling cell wall formation in the woody dicot stem. Plant Molecular Biology 47(1-2): 239-74.

Melo, L. E. L.; Silva, J. R. M.; Napoli, A.; Lima, J. T. L.; Trugilho, P. F.; Nascimento, D. F. R. 2016. Influence of genetic material and radial position on the anatomical structure and basic density of wood from Eucalyptus spp. and Corymbia citriodora. Sci For 44(111): 611-621.

Meylan, B. A.; Probine, M. C. 1969. Microfibril angle as a parameter in timber quality assessment. Forest Products Journal 19(4): 30-34.

Navi, P.; Rastogi, P. K; Gresse, V; Tolou, A. 1995. Micromechanics of wood subjected to axial tension. Wood Science and Technology 29(6): 411-429.

Neves, W. A. A. 2004. Chave de identificação de espécies florestais (CIEF).[on line] Piracicaba: IPEF. available: <http://www.ipef.br/identificacao/cief/>[cited: 4 nov. 2017].

Palermo, G. P. M.; Latorraca, J. V. F.; Carvalho, A. M.; Colonego, F. W.; Severo, E. T. D. 2015. Anatomical properties of Eucalyptus grandis wood and transition age between the juvenile and mature woods. European Journal of Wood and Wood Products 73(4): 423 -562.

Pires, J.V. 2010. Avaliação de características dendrométricas de eucalipto não manejado. 60 p. Monography (Forest engineering). Universidade Federal de Lavras. Lavras.

Plomion, C.; Leprovost, G.; Stokes, A. 2001. Wood formation in trees. Plant Physiology 127(4): 1513-1523.

Preston, R. D. 1974. The Physical Biology of Plant Cell Walls. Chapman \& Hall: London.

Ramos, L. M. A.; Latorraca, J. V. F.; Pastro, M. S.; Souza, M. T.; Garcia, R. A.; Carvalho, A. M. 2011. Variação radial dos caracteres anatômicos da madeira de Eucalyptus grandis W. Hill Ex Maiden e idade de transição entre lenho juvenil e adulto. Scientia Forestalis 39: 411-418.

Stuart, S. A.; Evans, R. 1995. X-ray diffraction estimation of the microfibril angle variation in Eucalyptus wood. Appita Journal 48(3): 197-200.

Tomazello-Filho, M. 1985. Variação radial da densidade básica e da estrutura anatômica da madeira de Eucalyptus gummifera, E. microcorys e E. pilulares. IPEF 29: 37-45.

Tomazello-Filho M. 1987. Variação radial da densidade básica e da estrutura anatômica da madeira de Eucalyptus globulus, E. pellita e E. acmenioides. IPEF 36: 35-42. $13-23$.

Wilkes, J. 1988. Variations in wood anatomy within species of Eucalyptus. Iawa Bulletin 9(1):

Wilkes, J.; Abbott, D. 1983. Influence of the rate of tree growth on the anatomy of eucalypt species". Appita Journal 37(3): 231-232.

Wimmer, R.; Downes, G. M.; Evans, R. 2002. Temporal vari- ation of microfibril angle in Eucalyptus nitens grown in different irrigation regimes. Tree Physiology 22(7): 449-457.

Yang, J. L.; Evans, R. 2003. Prediction of MOE of eucalypt wood from microfibril angle and density. European Journal of Wood and Wood Products 61(6): 449-452. 